\title{
'Spiritual humanism' within the realm of Christian aesthetics. Toward the meaning and value of our being human within the theological framework of an aesthetics of compassion.
}

\begin{abstract}
In the centre of Vincent Brümmer's philosophical and spiritual reflection is the quest for the meaning of the Christian faith, outside the parameters of positivistic schematization. This theological sensitivity stands in close connection to the ontological thinking of his promoter A. E. Loen: meaning is a kind of ontic, creational truth closely related to the noetic category of 'uitgesprokenheid' (explicit, expressed, pronounced logos). Brümmer himself has identified "Meaning and the Christian Faith" as the meanders of his thinking, thus the attempt to explore these meanders within the framework of a theological anthropology. With reference to man as homo aestheticus and the aesthetics of theopaschitic theology, the aesthetics of passion and compassion is described as divine Beauty. The passio Dei is an exposition of the praxis concept of ta splanchna. In this regard the notion of "bowel categories" describes a practical theology of the intestines which focuses on the dignity of our being human, thus the option for an inclusive 'spiritual humanism' within the framework of the ubuntu-communalism of African spiritualities (theologia Africana).
\end{abstract}

It was always difficult for Reformed theology to acknowledge the 'goodness' of our being human. This difficulty stands in close connection with the association in anthropology between our being human and the construct of corruptio totalis. Even Lutheran anthropology always tried to find a kind of 'rationalistic' balance between human sinfulness and justification: simul justus et peccator. Humans are therefore always crippled by their sinfulness and rendered as victims of the fall. Man has lost his/her sense for value, dignity, purposefulness. In essence humans are 'ugly' and bad old sinners. One can therefore expect nothing 'beautiful' from the beast. Life has become a toilsome burden and struggle against nausea, nothingness and sinfulness (failure). Sin always casts a devastating shadow over the human quest for meaning.

Very surprisingly Dostoyevsky describes in his novel The Idiot the 'goodness of man' as the playfulness of our being human; i.e. the enjoyment of life. Goodness ${ }^{1}$ then not as a substantial or metaphysical category innate to character, but goodness as a qualitative category within the dynamics of relationship. Dostoyevsky connects the celebrating view on the goodness of life to a divine enjoyment and playfulness. A simple peasant woman once said to him: "Just as a mother rejoices seeing her baby's first smile, so does God rejoice every time he beholds from above a sinner kneeling down before him to say his prayers with all his heart" (Dostoyevsky 1973:253). He viewed this remark as the essence of Christian spirituality: “God's rejoicing in man, like a father rejoicing in his own child" is to Dostoyevsky the fundamental idea of Christianity (1973:253). This spiritual notion of divine rejoicing is the difference between being an idiot or a wise human being; between devastating nausea and meaningful living.

Dag Hammarskjöld (1993:77) very aptly remarked: "A landscape can sing about God, a body about spirit". This cosmic singing (rejoicing) and spiritual interpretation can be called an

1 "Good" in the sense of a motion of trust in the covenantal faithfulness of God. (See Kuitert 1970: 25).

'Spiritual humanism' within the realm of Christian aesthetics. 73 
aesthetic vision and view on life.

For this aesthetic vision or iconic gaze one needs to rediscover a kind of 'Socratic view of life'. Life entails more than the flat horizontal and empirical approach of sensory observation; one needs to discover the ultimate cause of beauty.

Socrates wanted to penetrate the physical world by means of the notion of the goodness, the inherent beauty that contributed to the fact that things are as they are. In spite of a scientific explanation, he opted for an aesthetic option. "He is looking for explanations in terms of some ultimate Goodness which forms everything, including us, and draws us to it by means of spiritual knowledge and desire. We must consider not the things which Anaxagoras and the scientists speak of, but the real, ultimate causes of Beauty, Goodness, Magnitude, and so on, which the good and beautiful things and the quantities of things on earth participate in and reflect" (O'Hear 2007:108).

\section{PRESUPPOSITION AND BASIC ASSUMPTION}

What is most needed within a Christian approach to anthropology and the human quest for meaning is a paradigm shift from the destructive starting point of the fall, and a substantial understanding of human sinfulness, to the constructive starting point of the creation narrative and the recreation version: the eschatological point of reflection and the total but radical renewal of the whole of cosmos. Sin does not determine the quality of life and the framework of meaning but spiritual wholeness (heil, grace, salvation, redemption). It will be argued that the event of the cross (the ugliness of God) and the resurrection in Christ (theologia resurrectionis: the doxa of life) brought about a total paradigm shift. Life could not anymore be assessed from the perspective of death and sin, but from the perspective of grace and meaning.

With reference to anthropology, another paradigm shift is most needed. From the emphasis on work ethics, the human being as homo faber (performance, production and achievement), to the emphasis of playfulness and enjoyment: the human being as homo ludens. Fundamental to these paradigm shifts is the basic presupposition of man as homo aestheticus: the beauty, value and purposefulness of human life.

My theological assumption is that due to an eschatological stance (who we already are in Christ: we are a new creation) and the spiritual quality of life (due to the indwelling presence of God through the Holy Spirit in human bodies: the pneumatology of inhabitational theology), the power of grace is more substantial and fundamental than the temptation of evil and the seduction of the so called "human flesh". Human flesh is an aesthetic and therefore beautiful category not a corrupted and dirty category.

Central in Christian spirituality is the question regarding the meaning ${ }^{2}$ of the Christian faith and its connection to our understanding of the purposefulness of human life and the connection between our being human and the ultimate ${ }^{3}$. This anthropological presupposition dovetails with what Vincent Brümmer identified as the meaning of the Christian faith.

It was already the 'doctor father' of Vincent Brümmer, Arnold E Loen (1946:2, who related existential meaning and the philosophical impulse to personal accountability (rekenschap aan onzelf). This noetic accountability displays a kind of meaningful (in terms of significance) insight

2 On the connection between meaning and the Christian faith, see Gräb 2000; 2002; 2006. "Das Wort 'Gott' kann zu diesen Artikulationen religiöser Erfahrung gehören. Dann ist es Gott, dem der Mensch dankt für das Geschenk des Lebens oder den er bedrängt mit der Frage nach dem 'Warum'”. (Gräb 2006: 30). For the connection between meaning and religion in film and media, see Hermann 2002.

3 See Brümmer 2006: 299. See also the link with one of Brümmer's contemporaries Kuitert (1974: 20). The quest for the 'whole' is for Kuitert characteristic of our being human within the parameters of religion. 
in the logos, the ground and roots of our being human in the cosmos (Loen 1946:3). Meaning is determined by a Christian gnosis: God as the foundation of all being. Meaning is a kind of ontic, creational truth closely related to the noetic category of 'uitgesprokenheid'4 (an explicit, expressed, pronounced logos) (Loen 1946:200); knowing is to partake in the 'word'-character of revealed truth in a respond-able mode (Loen 1955:186-188).

"I have long been convinced that the primary function of religious belief within human life and thought is to bestow meaning and significance on our life and our experience of the world" (Brümmer 2006:26). As a philosophical theologian, Brümmer has therefore concentrated on questions regarding the meaning of the Christian faith. And meaning for him is a contextual issue embedded within living contexts. It is not a fixed proposition. "I have therefore always found unsatisfactory the kind of natural theology that tends to reduce religious belief to a set of propositions divorced from the context of life, and then to prove the truth of these propositions without first attending to their meaning" (Brümmer 2006:26). Due to the fact that Brümmer himself has identified "Meaning and the Christian Faith" as the meanders of his thinking, I want to explore these meanders within the framework of a theological anthropology, thus the introduction of the notion of homo aestheticus.

My further contention is that aesthetics in theology is closely linked to a theology of compassion. Compassion gives meaning to life. Dostoyevsky concurred with the assumption that without compassion life becomes an unbearable toil. Compassion makes life bearable. "Compassion would teach even Rogozhin, give a meaning to his life. Compassion was the chief and, perhaps, the only law of human existence" (Dostoyevsky 1973:263). Therefore I want to link the meaning question in this essay to a theology of oiktirmon in order to expand on the notion of homo aestheticus from the perspective of the poetics of God. My proposition is that the meaning of the Christian faith is not in the first place to keep God going by means of our rationalistic and positivistic profession on the essence or being of God (the positivistic attempt to define the being and characteristics of God), but to keep human beings going (the anthropological attempt to empower human beings and to equip them to live life meaningful) and, in thus doing so, to honour God (doxa). Hence the introduction of a 'spiritual humanism' in the discourse on the meaning of the Christian faith.

The intention is to embark on a qualitative approach to anthropology. Life in itself is dependent on the quality of relationships. Anthropology in a Christian spiritual approach should therefore point more in the direction of a qualitative mode of being (Heidegger: So-sein) emanating from the compassion of a Divine Passion.

Surprisingly I discovered that this was more or less the stance of Ludwich Feuerbach (1904). In chapter VI on the secret of the suffering of God (Das Geheimnis des leidenden Gottes) (1904:126-136), Feuerbach distinguished between the God of abstract philosophy, God as pure action, with the God of Christendom, God as pure passion, the God of pure suffering (die Passion pura, das reine Leiden) (Feuerbach 1904:127). The suffering of God means: God is a heart (Gott ist ein Herz) (Feuerbach 1904:131). A God without a heart is an idol. The secret of the suffering God is the secret of existential experience and tenderheartedness (Geheimnis der Empfindung; kontingente bevindelikheid). The meaning of Christian religion resides for Feuerbach in the notion of suffering. Vulnerability and weakness are constituents of suffering and human experience; they are signs of fulfilment and a divine force within our being human. (Feuerbach 1904:31). In an asterisk Feuerbach (1904:31)) further explains the divine signs of a suffering God, a God one can experience and find within the realities of weakness and vulnerability (ein empfindender, empfindsamer Gott). He refers to 'Bernhard': God wills suffering in order to learn what is meant by co-suffering; God wills pity and mercy (lament) in order to learn what is meant

4 "Wahrheit ist Ausgesprochensein des Seienden" (Loen 1965: 210). 
by compassion, comfort and consolation ${ }^{5}$.

I want to take the notion of Feuerbach seriously and as starting point for a theological reflection on the notion of spiritual humanism emanating from the God with a heart (passion) within the existential realities of human vulnerability.

In order to link anthropology to spirituality and meaning-giving, the essay will be divided into two main parts. Section one will be on the anthropological framework of meaning: man as homo aestheticus. The second part will be on the theological framework of meaning: meaning as compassion (the oiktirmōn ${ }^{6}$, compassion and mercy of God).

\section{THE DIONYSIAN, PLAYFUL PARADIGM}

The conviction that Christian "religion" should turn more to the Dionysian, playful element of faith, could disturb and uproot conventional faith and orthodox thinking with its traditional point of departure in the more serious element of human sinfulness, guilt and the need for salvation. Traditional faith often tended to distance itself from the so called 'temptations of secular society'. Over against an avoidance approach, Cox emphasised qualitative value of secularity and the non-instrumental significance of celebration and liturgy (1969:vii) in Christian spirituality.

Within the history of orthodox, Christian faith, the confessions of the church were mostly concerned with the formulation and definition of "true faith". Faith is designed for rational formulae not for aesthetic experiences. Ecclesiastical councils, synods and clergy wanted to defend ecclesial doctrine against heresy. Theology was designed to please God (it should be orthodox), not to 'please' (empower) humans (orthopraxis). Faith is a serious business, not a playful enjoyment. Questions about right and wrong, good and evil, were more 'spiritual' than questions about sensual beauty and bodily pleasure.

The reason why John A. T Robinson exposed theism in his 1963 book Honest to God, was inter alia to turn theological reflection away from a metaphysical paradigm to the reality of our being human within the realm suffering. Instead of the abuse of God as a Deus ex machina, Christian spirituality should be directed by the powerlessness of a suffering God (Robinson 1963:39). God is not like a Grandfather in heaven, a kindly Old Man who could be pushed into one corner while we get on with the business of life (1963:41). "God, the unconditional, is to be found only in, with and under the conditional relationships of this life: for he is their depth and ultimate significance" (Robinson 1963:60).

In the sixties of the previous century, H. W. Cox pointed out that the so-called "death of God" is not merely an intellectual death. It is also intuitive and aesthetic (Cox 1969:28). According to Cox, if we really want to "experience" and "encounter" God, we have to meet him first in the dance before we can define him in the doctrine (Cox 1969:28). I want to add: if we really want to be embraced by God, we have to meet him first in the beauty of life and the aesthetics of human embodiment, before we can capture and comprehend him in the confessional formula of the church; we must be embraced by compassionate vulnerability first, before we worship in the safe space of a baroque cathedral.

5 "Leiden wollte er, um mitleiden zu lernen, erbärmlichwerden, um Erbarmen zu lernen". I assume the reference to Bernhard is a reference to Bernhard von Clairvaux. The German is difficult to translate because erbarmen (Afrikaans erbarming) implies more than pity. It is a combination between pity, mercy and care.

6 The Hebrew root rhm refers to compassion. It is also closely connected to hnn, to be gracious. Esser 1976: 598. 
Cox's attempt to revisit secularism by probing into the constructive elements of secular thinking, met a lot of resistance and criticism from orthodox faith. In the northern hemisphere it fuelled the secular city debate (Callahan 1966). In many conservative circles theologians responded with severe criticism and scepticism. Cox was accused of a kind of humanist optimism that emphasises man's maturity and responsibility, with the attendant danger of neglecting the Crucifixion. Instead of a partnership with God, the emphasis in conventional thinking is the anguished cry of sinners: "O wretched man that I am, who shall deliver me from the body of this death" (Smylie 1966:11).

To my mind, the most intriguing question in the Christian faith is whether faith is in the first place about confession (the acknowledgement of our sinful human predicament) or about profession (the affirmation of our being before God); whether it is about renunciation of all worldly things or the celebration of life. What comes first: morality and sin or aesthetics and gratitude?

Could it indeed be the case that traditional Christian faith pressed human beings so hard towards work, rational calculation and salvation from sin, that Christians have almost all but forgotten the joy of ecstatic celebration, antic play, free imagination and aesthetic gratification? The church developed a kind of spiritual blindness due to what one can call the unfortunate twisting of life.

Some of the most basic twists (unfortunate spiritual confusions) in Christian faith are outlined below.

- The Platonic schism between body and soul. This dualism shunted the human body into the realm of filth, dirt, guilt and shame.

- The metaphysical speculation about the beyond of an immutable theistic God which superseded the passion and compassion of a suffering, weak God (theopaschitism).

- The inaccurate translation of the unique splendid majesty of the covenantal involvement of a faithful and merciful God (el shaddaj) as the imperialistic force of an almighty Hellenistic Pantokrator (the omnipotence of God).

- The selling out of the kingdom of God as embodied in the sacrifice of a vulnerable Christ (sacrificial ethics) to the monarchic imperialism of a Caesar-like political ecclesiology (performance and achievement ethics). The hierarchy of powerful clergy dressed in crowns, surrounded by the imposing baroque palace-like cathedrals, was more impressive than the rags of beggars and the shacks of township people.

- The confessional formulation of the Christian faith as truth in terms of doctrinal and prescriptive formula or rational propositions, rather than the understanding of the gospel and the truth of faith in terms of wisdom thinking and relational terminology, i.e. expressing truth within the dynamics of life. The doctrinal focal point was less on the healing of human relationships and the restoration of human dignity and justice by means of the "beauty", the aesthetics, of unconditional love. Doctrine was supposed to promote confessional spiritualism rather than "spiritual humanism". Ethics (morality and the distinction between good and evil) was more fundamental than aesthetics (iconic visioning and the distinction between beauty and ugliness).

- The notion of corruptio totalis in anthropology, i.e. that human beings are totally corrupted by $\sin$ and not able to do any good. With reference to, for example, Psalm 52 the confession of David (his whole being is assessed as being corrupted and infiltrated by his personal transgression), was most of times hijacked by ecclesial moralism to construe a 
doctrine of sin: the destructive and pessimistic notion of corruptio totalis. The connection between Adam and Christ was used to conceptualise a whole ontology of sin. What for David was a personal confession and an existential acknowledgement, became a doctrinal issue for the theological justification of human failure. David's acknowledgement of the disastrous impact of his transgression led him to the point that he linked his guilt to even the period of the foetus. His confession is rather an indication of existential remorse and personal guilt before God, than a doctrinal statement regarding ontology (the essence of being) and anthropology (the essential corruption of sinful human beings). Rather than being a metaphysical explanation about the origin of sin, the connection between the first Adam of the fall and the second Adam of the incarnation (Christ) should indicate the integrity of a divine intervention within the predicament of fallible human beings. The second Adam version points to the seriousness and integrity of the faithfulness of God to his covenantal promise "I will be your God" rather than to the total condemnation of the whole of cosmos. In order to safeguard a kind of equilibrium between justification and sanctification, the notion of simul iustus et peccator was introduced. But how can the eschatological fact that the whole of our being human was transformed by the cross and resurrection of Christ into a new being, the truth of the gospel that we were transformed from the realm of darkness into the realm of light, be balanced out with evil and sin?

- Even the confessions of the church revolve around the ugliness of sinfulness. For example, the form for baptism starts with: "That we with our children are conceived and born in sin, and therefore are we children of wrath, so that we cannot enter into the kingdom of God, except we are born again". The canons of Dort starts as follows: "As all men have sinned in Adam, lie under the curse, and are deserving of eternal death, God would have done no injustice by leaving then all to perish and delivering them over to condemnation

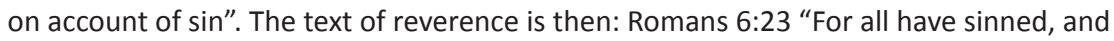
fall short of the glory of God".

\section{FROM THE UNFORTUNATE TWISTING OF LIFE TO 'SPIRITUAL HUMANISM'}

A Hellenistic paradigm is about the analytical split between matter an spirit. However, secularisation as a typical North American and Western European reaction to a theological positivism, is not first on the agenda of African spirituality ${ }^{7}$. For Africa and communities struggling with poverty and oppression, the secular debate seemed to be a luxury, more appropriate in an affluent society than within a context of severe suffering, discrimination and stigmatisation. The twentieth century was for Africa the epoch of struggle and the quest for freedom. While the Northern hemisphere struggled with secularism, Africa fought against colonialism. The point is: marginalised people and suffering believers, exposed to poverty, did not have extra spiritual energy to enter into the luxury of a God-is-dead debate.

Without any doubt Christian spirituality was for many believers in Africa a source of empowerment rather than embarrassment. In the struggle against colonialism, and in South Africa, against apartheid, the Christian faith helped believers exposed to racial oppression to

7 In Western Christian doctrine we have placed an enormous emphasis on justification and the notion of human beings as sinners. We have also placed an enormous emphasis on a human being as worker (Luther and Marx) and a human being as thinker (Aquinas, Descartes and orthodox doctrine). We sanctified the mind as the faculty of soulfulness excluded and deprived of any form of embodiment. Our celebrative and imaginative faculties have atrophied (Cox 1969: 11). One can even add: our aesthetic and imaginative faculties have mummified under the pressure of the sinfulness of embodiment. The body is dirty (ugly) and the soul is pure (beautiful). 
articulate their resistance to discrimination and stigmatisation. Ministers often used the slogan "God never sleeps" in order to motivate Christians to hope and to fight against oppression. The identification of God with the struggle of oppressed people became an icon of hope. The struggle in South Africa opened the eyes of the church for the freedom, dignity and rights of human beings within a sense of communality and belongingness. This quest for meaning and human dignity can be called the quest for a 'Christian humanism'.

\section{CHRISTIAN HUMANISM}

It was the former president of Zambia, Kenneth Kaunda, who wrote a book in the 1960s: entitled A Humanist in Africa. He advocated a humanist approach to life (Christian humanism) because of the communal spirit within different African spiritualities. For Africa the aesthetic rhythm of life, the singing and dancing, was more fundamental than the awareness of evil forces that determine the value of human relationships. Hence the following challenging remark by Kenneth Kaunda: "Let the West have its Technology and Asia its Mysticism! Africa's gift to world culture must be in the realm of Human Relationships" (1967²:22).

The spirit of ubuntu - that profound African sense that we are human only through the humanity of other human beings - is not a parochial phenomenon, but has added globally to our common search for a better world (Mandela 2005:82). And to improve the world is intrinsically an aesthetic endeavour, not merely a moral issue.

In an African approach to anthropology, ubuntu thinking and the notion of homo aestheticus (the human being as the enjoyer of life) are more fundamental than the aggressive approach of homo faber (the human being as the maker of things). What is envisaged in an African spirituality is harmony (the beautification of life) within interpersonal relationships: Umuntu ungumuntu ngabantu/motho ke motho ka batho - approximately translated as: "A person is a person through other people" (Mtetwa 1996:24).

This notion of mutuality and interconnectedness, a kind of 'spiritual humanism', is aptly depicted in the following African crucifixion by an unknown African artist, bought by myself from a pavement artist in Cape Town (Owner: D J Louw, chapel, faculty of theology).

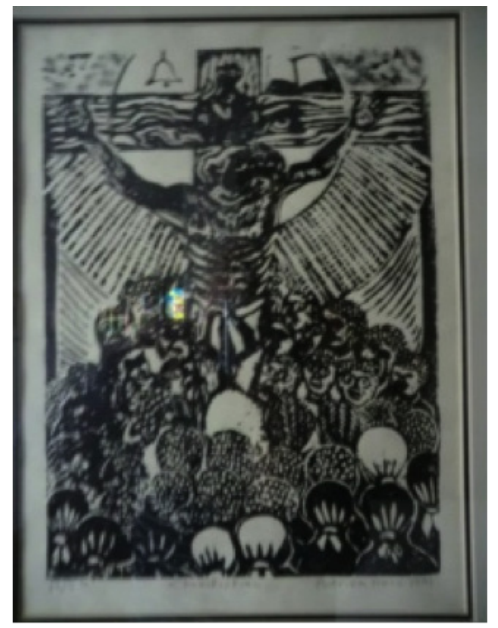

An African depiction of the cross, encircled by people; a humanist, ubuntu-Christ within the communality of life and human relationships. 
One of the most remarkable and tangible dimensions of African spirituality relates to the unique notion of communality and collective solidarity that African societies exhibit in all spheres of life. There is a profound sense of interdependence, from the extended family to the entire community. In a very real sense, everybody is interrelated; this includes relations between the living and those who have departed. African spirituality is structured, not along the lines of a pyramid, but of a circle - community and communality as the centre of religious life (Bosch 1974:40). ${ }^{8}$

Anthropology in an African paradigm is indeed about a homo aestheticus within the dynamics of interrelatedness, namely that a person is gripped or governed by a particular concern which is of central value to that person or a group of people. It affects a person's way of thinking, acting and feeling.

Spirituality thus reflects ultimate and aesthetic values within cultures; spirituality is concerned with life as a whole. "It is not a pious behaviour but rather a commitment and involvement in a manner that gives meaning to life. Spirituality means that unseen dimension which influences a person to live in a mode that is truly fulfilling" (Skhakhane 1995:106). To live is to celebrate life within the rhythm of daily events. And life fulfilment is to experience, despite the overwhelming awareness of the transience of life, that life can indeed be beautiful.

\section{HOMO AESTHETICUS: THE BEAUTIFICATION OF HUMAN LIFE}

"Man is homo festivus and fantasia homo" (Cox 1969:11). One can even say that the attempt to formulate the Christian faith in rational categories and to define God in terms of a correct doctrine (true confession), turned the Christian faith in the direction of scientia (scientific knowledge, the positivistic knowledge of the mind), rather than to sapientia (wisdom and the devotional knowledge of the heart). As Cox very aptly remarked: "Scientific method directs our attention away from the realm of fantasy and toward the manageable and the feasible" (Cox 1969:10).

In 1992 Ellen Dissanyake wrote a book with the title: Homo Aestheticus: Where Art comes from and Why. Her basic assumption was that aesthetics and art can be regarded as a natural general proclivity that manifests itself in culturally learned specifics such as dances, songs, performances, visual display and poetic speech. Art makes life special because art making involves taking something out of its everyday and ordinary use context and making it somehow special - the ordinary becomes extraordinary.

A human being is essentially homo aestheticus: the innate need for creative imagination; i.e. the making of transitional objects as means of overcoming loss and the limitations set by suffering and vulnerability. The human being as homo aestheticus refers to visionary anticipation and artistic appreciation within the quest for meaning and the creative attempt to signify and decode the markings of life.

Aesthetics coincide with the human quest for meaning and attempts of meaning-giving.

\section{Signs and significance: the deciphering of meaning ${ }^{9}$}

The following remark of the young Benedictine novice in the monastery of Melk summarizes

8 For the notion of a holistic spirituality in this regard, see Krezschmar 1996:63-75. A holistic spirituality seeks to integrate rather than separates the various dimensions of human experience (67).

9 In the book Wie Kunst die Welt erschuf Nigel Spivey (2006: 14) asserts that art is not merely the ability to craft (Handwerkliches Können); not merely the endeavour to beautify. Art emerges from the dynamics between human's creative ability and imagination/fantasy. The explosion of creativity in art is a mode of signifying life (Spivey 2006: 24). 
it all: "But we see now through a glass darkly, and the truth, before it is revealed to all, face to face, we see in fragments (alas, how illegible) in the error of the world, so we spell out its faithful signals even when they seem obscure to us and as if amalgamated with a will wholly bent on evil" (Umberto Eco: 1980:11).

Signs can be called the semiotics of the arts (Hess-Lüttich, Rellstab 2010:247); signs signify "something". Whether the something is a concrete object or the product of impression or imagination, a piece of art refers in one way or another to an "idea" as related to context, form and content (Belton et al 2006:11-13). In this respect one could say that Plato was perhaps correct when he argued that imagining is related to a form that refers to an idea which expresses the quest for truth ${ }^{10}$.

\section{Aesthetics and the poetic question}

One can walk through life like a "wise fool", leaving behind signs which function as poetic images to be interpreted: ut pictura poesis ${ }^{11}$ (life as a poetic image). Even a human being becomes a poetic image, or, in the words of the Dutch theologian A. A van Ruler, a kind of theopoiesis (Rebel 1981:145), reflecting the authentic 'beauty' of the divine Spirit within the realm of the humanum (theonomous humanity).

According to Thomas Aquinas integrity (integritas), harmony (consonanta) and clarity (claritas) can be described as the principles of beauty. They can also be interpreted as wholeness, proportion and luminosity (Skawran 2012:3). The poetic question and the quest for beauty kindles quest for congruency between viewer and an object. Within this dynamics, aesthetics can be described as the attempt to move images into the realm of imagination (Botha 2012:5).

Pictura poesis indicates that life is more than reasoning and seeing; life is poetic imaging ${ }^{12}$; a silent poem to be interpreted. Applicable in this regard is the Ciceronian formula: poema loquens picture, pistura tacitum poema (poetry is a spoken painting; painting is a silent poem) (Huyghe 1981:20).

The Greek Polyclitus and the school of the Pythagoreans (In Hess-Lüttich, Rellstab 2010:247) called a piece of art the attempt to express perfect interrelatedness of different components to one another; it wants to explain how the different parts are related to the whole. Aesthetics is therefore involved in the human attempt to express a kind of order (relationship) (truth) despite the chaotic appearances of threatening phenomena. Even if a piece of art is called "ugly"13,

10 The urge to signify "the more", the yearning for "spirituality" beyond the limitations of reason and logic was well articulated by surrealism in the twenties of the previous century.

Rookmaker (1973: 144) pointed out that the upcoming of surrealism in the early twenties, is an indication of a revolt against the structure of reason. "Their aim was a liberation of life, in every aspect, to free man from this strange world that holds him in a thousand ways; on the basis of Freudianism they wanted to liberate man from convention, culture and society. The third issue of La Révolution Surréaliste said: 'Ideas, logic, order, Truth (with a capital T), Reason, all this is given to the nothingness of Death. You do not know how far the hatred we have against logic can lead us."

11 The formula of Horace, in Huyghe 1981:20.

12 The poetics of life is about the quest for spirituality. In her book Image and Spirit Karen Stone (2003: 9-11) describes art as a spiritual voice, as a process of imaging. "Art at its best makes concrete what language and especially religious language cannot: that intangible, private or communal moment when we encounter being". Art is about the poetics of life; it is a spiritual endeavour probing into the depth dimension of being; "...that is, the ontological, the essence of experience beneath and beyond the surface appearance of things" (Stone 2003: 11).

13 In his Les Demoiselles d'Avignon, Picasso reveals a kind of barbaric destructiveness that horrified his friends and the art society: “...five horrifying women, prostitutes who repel rather than attract and whose faces are primitive masks that challenge not only society but humanity" (Huffington 1988: 93). In an interview in Die Burger (La Vita 2012: 13) the South African sculptor Dylan Lewis referred to this intra- 
disturbing, or incomprehensible abstract, art is both public and iconic; there is no private work (Hess-Lüttich, Rellstab 2010:270) or non-spiritual artistic piece ${ }^{14}$.

\section{The mediation function of aesthetics within the quest for some-thing (eidos)}

Matzker Reiner (2008) relates aesthetics ${ }^{15}$ to the act of mediation within the tension between subject (impression and interpretation) and object or the implicit idea as related to an object or something perceived and observed. To mediate is always a sign for something (2008:10). Mediation operates within the connections between form (eidos; essence, meaning) and matter (hýle, ontic dimension). The projection of what is observed and seen implies in the act of mediation and representation virtuosity: skill, competence and know-how; i.e. artistic proficiency.

The mediatory function of a medium is to communicate, to inform, to disclose, to make something knowable. Aesthetics becomes an instrument (medium), an image (means) about some-thing (content). It transcends its own limitations in the direction of signification. In this regard aesthetics symbolizes (from the Greek symbálein = to link to halves) and refers to meaning. (Matzker 2008:10). Aesthetics then expands the interpretation horizon of human beings; it creates a grammar of mediation. For Plato the mediation points in the direction of a copy of a kind of original image or existing idea. For Aristotle the mediation is in itself a process of signifying in the sense that it functions as a memory (Anamnese) to reality (Matzker 2008:1112).

The important point is that in aesthetics there is a constant interplay between reality, image and significance, particularly in the sense that through mediation aesthetics becomes the attempt to represent some-"thing". A human being therefore as homo aestheticus is not merely a some-thing. A human being is a some-body mediating the aesthetics of God, the creative Artist of life.

\section{Human embodiment as the aesthetics of the human soul}

The portrayal of the divine in terms of a human figure was always a disputable issue in orthodox theology. Michelangelo made a kind of "breakthrough" in the sense that he viewed the perfect human figure as a representation of God (divine embodiment) or Christ not as a "graven image" to be worshipped (idolatry) but as a depiction of the beauty of God (God's love) as reflected in the essence of the human soul ${ }^{16}$. At the same time, the movement and proportions of the human body are always framed by torment and suffering.

psychic transcendence as an "inner wilderness".

14 Pablo Picasso said: "There is no abstract art. You must always start with something. Afterward you can remove all traces of reality. There's no danger then, anyway, because the idea of the object will have left an incredible mark" (In Barr 1975: 273). This "mark" can be called an aesthetic sign to be deciphered in the human quest for meaning and truth. Truth and meaning are intertwined with one another within processes of signification.

15 According to Jochen Schulte-Susse (2010: 758-778) aesthetics should be linked to theory on perspective (perspectivism). The theory of perspective is about the question how to resemble a three dimensional object on a two dimensional surface, or how to represent a three dimensional object via a material form or sculpture so that the representation and image of the object, the idea within the object, corresponds with the proportions of the immediacy of the act of seeing, feeling and experiencing. In terms of Jacob Boehm's theory on aesthetics, aesthetics links with the intention and value assessment of the subject in relationship with the viewed or observed object.

16 From Socrates Michelangelo learned that the purpose of painting was to present the human soul, the life of human souls, as an expression of the very internal being of humans. According to Néret (2006:

32) Michelangelo was only interested in the people he painted due to the fact that perfect bodies were the carriers and containers of the idea of eternity. 

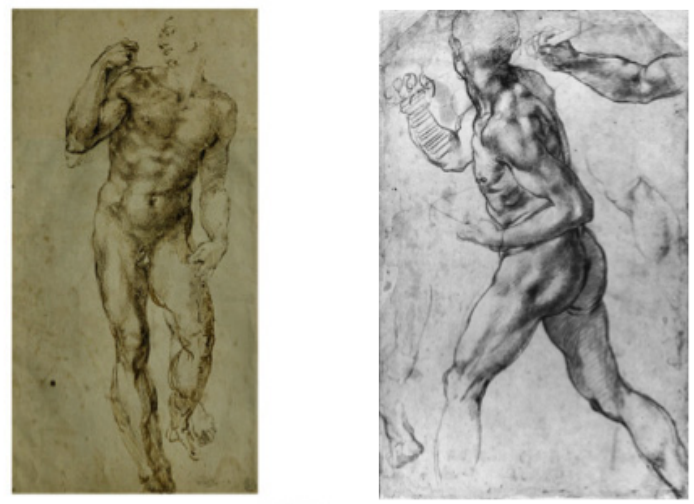

Michelangelo: The rhythm of the perfect human body as indication of the divine movements of the human soul ${ }^{17}$

The meaning of the Last Judgment resides not in the naked bodies but "the shop wreck of entire tormented and suffering humanity...anxiously awaiting the fulfilment of the promise that in the presence of Christ the Judge and Redeemer the righteous will rise from the dead at the end of time" (Vecchi in: Paris 2009:175).

K Schoeman in his book on Michelangelo Buonarroti (2009:555) refers to the fact that in his reflection on life and its purpose, it was all about the attempt how to bridge the gap between God and human beings by means of the aesthetics of beauty, the expression of love and the imaging of art. The beauty of the cosmic body within its imperfect earthly realm, as well as the attempt to depict it in painting and sculpturing, serve as a vehicle to glorify God.

For Michelangelo imaging in art is iconic because it is helping him to approach the perfect beauty of God (Schoeman 2009:559). To capture human embodiment is to capture the ensoulment of life and the aesthetics of God.

\section{The naked human body: pornographic striptease of the human soul?}

Within Greek art the naked human body and its perfect symmetry equals beauty and should be assessed as a piece of art. Spivey (2006:75) refers to the canonization of human embodiment in art by Polyclitus. For Polykleitos the human body is from an aesthetic point of view perfect due to the tension between symmetry, balance and harmony. The naked human body therefore reflects dynamics, balance and harmony not pornography18.

17 Online: http://www.google.co.za/imgres?imgurl=http://www.lib-art.com/imgpainting/4/9/14294-malenude-michelangelo-buonarroti.jpg\&imgrefurl=http://www.lib-art.com/imgpainting/4/9/\&usg= olOshIWHVCeI-KaflL47uFUg5E $=\& \mathrm{~h}=1177 \& \mathrm{w}=750 \& \mathrm{sz}=105 \& \mathrm{hl}=$ en $\&$ start=9\&zoom $=1 \&$ tbnid $=$ AUVF5 9hBZE75rM:\&tbnh=150\&tbnw=96\&ei=mpuAT_n3Csz3mAX75fjZBw\&prev=/search\%3Fq\%3DMichela ngelo\%2Bdrawings $\% 2$ Bmale $\% 2 B n u d e \% 26 h l \% 3$ Den $\% 26$ sa $\% 3$ DN\%26biw $\% 3$ D $983 \% 26$ bih\%3D440\%26 gbv\%3D2\%26tbm\%3Disch\&itbs=1.Assesed: 06/04/2012.

18 During Pius V's pontificate, the Congregation of the Council of Trent decided, on January 11th, 1564, to have the private parts cover. The most pornographic decision in the history of Christian spirituality! Pope Paul IV therefore summoned the House of Carafa Daniele da Volterra to cover the genitals. The artist who did the covering was given the name "Braghettone" meaning "trouser painter"(Néret 2006:78). 
Pornography is derived from two Greek words, pornay and graphay (Melton et al. 1989:68). Pornay is derived from peraymi which means "to sell," usually in reference to a slave or prostitute for hire. Graphay refers to that which is written, inscribed, or pictured. "Pornography" then literally means to picture or describe prostitutes, with the connotation of an unequal slave/ master relationship.

Pornography is therefore not nakedness as such (see the statute of David by Michelangelo and the paintings in the Sistine Chapel), or explicit sexual pictures or portrayals of sexual acts, or erotic material, stimulating sexual excitement. The criterion cannot be sexual excitement or fantasy, because then any stimulation or visual impression related to sexual connotations and to sex will fall under the category of pornography.

Pornography refers very specifically to sexual exploitation and the dehumanisation of sex so that human beings are treated as things or commodities (Court 1990:929). Pornography points in the direction of the depiction or the description of the unequal misuse of power and violent sexuality (physical and psychological violence against others and oneself) promoting promiscuity. The genitals then become playful tools (the instrumentalisation of physiology) not intimate, sacred icons.

The advantage of the Michelangelo perspective on the aesthetics of human embodiment is that introduces a paradigm shift in anthropology from the hedonistic perspective of promiscuity to the aesthetic perspective of beauty; from the performance of sexuality to the enjoyment of sexuality. In fact the human body and the genitals are not designed to destroy and to ruin, but to heal, to beautify and to console, to comfort; to bestow compassion in life.

\section{MEANING AS COMPASSION: THE THEOLOGICAL FRAMEWORK}

Power, even the power of God, is most of the times defined as domination and control (Pasewark 1993:2). This understanding of power always presents the need to defend the notion of God's omnipotence on philosophical and theological grounds and for reasons of religious life.

The Confession of Faith (Belgic Confession) starts with the notion of power as the creation, preservation and government of the universe. God as Father "watches over us with paternal care, keeping all creatures so under his power that not a hair of our head (for they are all numbered), nor a sparrow can fall to the ground without the will of our Father..." Although "will" is not mentioned in the Greek text (Matthew 10:29; literally: without our Father), the interpreters read "will of the father" into the text. In the background of the religious mind, God determines everything so that the will of God should at least equal divine power. Divine power is then interpreted in terms of cause and governance (strength) and not in terms of care and compassion (vulnerability).

The point is: strong and powerful people need strong and powerful deities (Hall 1993:108).

In the history of the church the Christian establishment was deeply influenced by a religion designed to serve the purposes of empires. Influenced by Constantinian imperialism, theology exploited the power potential of the Christian God and minimised everything reminiscent of divine vulnerability and self-emptying.

The "Father Almighty" developed under the influence of an affluent society into the romantic sentimentality of Father Christmas All-merciful. Instead of a suffering God, the triumphalism of a theology of glory "removed the cross from the heart of God" (Hall 1993:96).

"God is depicted as one who, unlike us, does not exist under the threat of nonbeing in any of its manifestations. Thus, the divine power (omnipotence) is not challenged by any lack or weakness; the divine knowledge (omniscience) is not circumscribed by ignorance, uncertainty, or inherent limitation; the divine presence (omnipresence) is not subject to the constraints of 
time and space; and God is not vulnerable to change or prey to passions that may be aroused by any existential eventuality (immutability)" (Hall 1993:96-97).

Mostly it is our understanding of power in politics and the social sphere that dominated both our understanding of God and the meaning of our being human. Our common use of power takes political power as its exemplar; power as domination. The perfection or fulfilment of power as domination easily becomes manifest as "absolute power", "the tyrannical enslavement or eradication of whatever opposes such power" (Pasewark 1993:3). When projected on to "God Almighty", God appears as the invincible tyrant or judgmental judge. The whole of the Christian life and the realm of religion are then framed by a rule-governed supervision of action as prescribed by ethics and the iron will of God. There is then virtually no space for ethos, a purposeful end (telos $)^{19}$, the aesthetics of life, the aesthetics of existence, the beauty of creation. As a prescriptive rule (legalism) ethics dominated ethos, "correct truth" (positivism) supersedes aesthetics.

Very surprisingly, over against the power of defensive faith, Paul comes up with a startling thesis that is contrary to the powers that reside in theology and the church (Caputo 2007:62): vulnerable faith and the weakness of God frame the meaning of true Christian faith. Vulnerability and weakness suddenly became powerful categories. Within the power or charisma of the Spirit, they are designed for the empowerment of human beings deprived of dignity and 'beauty' because of the ugliness of inhumane stigmatisation and discrimination.

Paul links God to the event of suffering and introduces the "weakness of God"; the logos of the cross (logos tou staurou). This notion of power is marked as "foolishness" (a variant of the aesthetic category of ugliness). The power of human beings (ousia) is challenged by the 'weakness of God' which is stronger than human strength (I Cor.1:25). Why? Because it affirms God's identification with the vulnerability of suffering human beings. It opposes destructive domination and affirms constructive opposition. God becomes the helpless innocent victim of the Roman soldiers. The sacredness and divinity reside in the cry (derelicito) of protest: "My God, My God why have you forsaken me?" With the act of forgiveness, Jesus as the icon (eikon) of God, not of Roman power, became an innocent and helpless victim of Roman imperialism.

The evangelistic praxis of the church still functioned under the spell of the Constantine exploitation of power (Hall 1993:106). The subconscious framework was the corpus christianum with its inherent zeal to maintain both a political and spiritual power by means of the "almighty Christian God". Praxis was consciously, but perhaps mostly unconsciously, an imperialistic endeavour. The gospel and the church were viewed as something which has to be established as an empire. As D Hall (1993:106) pointed out: to sustain the power of an authoritative powerful church-praxis every form of tenderness and weakness is deleted, because weakness is not "the blueprint for a god designed for empire". A very specific understanding of both the power of the church and the power of God fed this imperialistic thinking. God was the masculine patriarch of civil society, an omnipotent "Caesar" 20 who can do everything and the immutable principle of life who can act as the metaphysical cause of everything that befalls us and happens in life. The church functioned as a political entity who can prescribe the policy of governments ${ }^{21}$.

19 For the connection between telos and aesthetics, see Pasewark 1993: 36. 'There is a telos, an end, toward which the ethical life orients itself. To be sure, it may be an aesthetic telos rather than a rule-governed supervision of action, but the ethical life is not devoid of meaning. The project of 'aesthetics of existence' is, in fact, a project of meaning creation".

20 Christian orthodoxy are based on God-images from which most traces of tenderness have been expunged. W N Pittinger (in Hall 1993:54) argued that the typical picture of divine omnipotence is a case of "giving to God that which belongs exclusively to Caesar". Even the love of God became a masculine affair supported by patriarchalism.

21 The "popes" of synods dictated the politics of the day. If it is true that different races and the variety 
In this regard Browning (1983:13) refers to David Tracy who believes that practical theology has primarily to do with the criteria or norms for the transformation of human brokenness (being reality). Our human suffering and the quest for meaning determines all forms of praxisthinking. Theological praxis should therefore be framed by the suffering passion of God (the very ontology of the heart of God), and not in the first place by the immutable and rational Council of God (positivism of the Mind and "Raad van God"). Praxis-thinking as a theological endeavour, is inevitable passion-thinking as com-passionate being-with.

\section{TA SPLANCHNA: THE PASSIO DEI IN THEOPASCHITIC THEOLOGY}

In the effort to identify God with human suffering, theopaschitism became the theory or doctrine by which theology tries to construe a more passionate approach to our understanding of God's presence within the reality of human suffering (injustice, poverty, stigmatisation, discrimination, stereotyping, illness, violence, the abuse of power, tsunami's, catastrophes).

A theopaschitic approach 22 , which leans strongly towards divine pathos, acceptance and understanding, has been welcomed by those theologians who wanted to reframe paradigms regarding God's praxis. No longer is God seen as static and absolute, but dynamic, thereby opening up the future for human existence ${ }^{23}$.

The value of theopaschitic thinking for the praxis of God is that it proposes a shift from the substantial approach to the relational and encounter paradigm (Berkhof 1979:32-33). The switch is then from the attempt of orthodoxy to uphold ecclesial triumphantilism (Hall 1993:100-101) and a theology of glory (theologia gloriae) and omnipotence (powerful force) ${ }^{24}$, to a theologia crucis $^{25}$ of weakness, suffering and passion.

It is my contention that the passio dei is an exposition of the praxis concept of ta splanchna. The latter is related to the Hebrew root rhm, to have compassion. It is used in close connection to the root hnn, which means to be gracious. Together with oiktirmos and hesed, it expresses the being quality of God as connected to human vulnerability and suffering (H.-H. Esser 1976:598). The verb splanchnizomai is used to make the unbounded mercy of God visible; it displays a strange kind of divine Beauty. It describes a theological aesthetics. In a theological aesthetics, beauty should therefore be connected to the pathos of the crucifixion. "This em-pathos, mediated by their own distinct accounts through the beauty of the crucifix, in turn becomes, second, sympathos - a plea for divine sympathy with their own suffering" (Garcia-Rivera 2008:177).

Ta splanchna ${ }^{26}$ reveals God as a Presence, 'a Companion, "your God"' (Hall 1993:147). In

of cultures is the will of God, "apartheid" should be the solution to the possible tension and differences between races. If it is indeed the case that women are inferior to men, patriarchic thinking should be justified by theology in order to keep women from church decision-making and official functioning.

22 Some of the most important proponents of theopaschitism are the following: God's weakness

(Bonnhoeffer 1970); God's powerlessness (Sölle 1973); God's being as an event of becoming (Gottes Sein ist im Werden )(Jüngel $1967^{2}$ ); God's forsakenness (Moltmann 1972); God's defencelessness (Berkhof 1973; Wiersinga 1972)

23 Although the pathos concept suggests evidence of God's genuine involvement in suffering, there is a danger that the distinction between the passio Dei and the passio hominum can easily fall away. God's sovereignty (transcendence) can easily be sacrificed by an overemphasis on God's enfleshment and identification (condescension).

24 See in this regard the remark of Hall 1993:108): "Powerful people demand powerful deities - and get them!"; "Power - and precisely power understood in the usual sense - is of the essence of divinity shaped by empire" (1993:107).

25 "Greek epistemology could not take account of the surprise needed to recognize God on the cross ...It did not envision suffering as a source of knowledge". Jon Sobrino in Hall 1993: note 8, p105.

26 It is interesting to note the cases where Christ responded to human suffering with the contraction of 
praxis-thinking it is not the task of the church to demonstrate that God must be, but to bear witness to God's being-there, being-with, and being- for the creature. In terms of D Hall (1993:155) the test of the church's God-talk at any point in time is it contextual authenticity, its praxis-thinking: does it illuminate God's being-with-us? We can add: does it portray God's beingwith-us as ta splanchna ${ }^{27}$ ?

Splanchnizomai reveals the very character of God within the messianic involvement and engagement with human suffering. The theology of the entrails ${ }^{28}$ reflects God's being quality, and can be called the ontology of God's beauty in suffering.

From a practical point of view the general and traditional theological question is always the cause-effect question: why God and weather God is behind these cases? From a praxis point of view the question is not whether God is behind these events, but what is God's attitude and intention within these events; what is the mode of God's being within our human predicament. The texts totally reframe our understanding of who God is and what is meant by God's power, now understood as passion and compassion (oiktirmon) and not in the mode of Caesar-like power ${ }^{29}$.

By his suffering, God shows that He is weak, vulnerable and powerless in this world. Only Christ's weakness can help us to resist suffering in an attitude of protest/resistance and surrender (Widerstand und Ergebung).

The theopaschitic approach clearly links God with suffering. The cross completes this link and this reveals God as a 'pathetic' being: He is the 'suffering God.' Feitsma (1956) calls this form of theopaschitism (redefining God's Being in terms of suffering) the most ultimate expression in theology of what is meant by God's compassion. ${ }^{30}$

the entrails, expressing messianic compassion. For example the leper with his petition (Mk.1:41), the people like sheep without a shepherd (Mk. 6:34); Matt.9:36: the sight of the harassed and exhausted crowd; Matt. 20:34: two blind men who besought him; Lk. 7:13: the widow at Nain mourning her only son. In Lk. 15:11-32, the prodigal son, splanchnizomai expresses the strongest feeling of a merciful and loving reaction (verse 20). In the parable of the good Samaritan (Lk. 10:33) splanchnizomai expresses the attitude of complete willingness to use all means, time, strength, and life, for saving at the crucial moment (Esser 1976: 600).

27 In general Greek to splanchnon refers to the valuable parts, the heart, lung, liver, but also the spleen and the kidneys. During the sacrifice they are removed for the sacrificial meal. With reference to human splanchna refers to the human entrails, especially for the male sexual organs and the womb, as the site of the powers of conception and birth. Within metaphoric speech ta splanchna expresses pity, compassion and love. "The oldest form of the verb is splanchneuō, eat the entrails, prophesy from the entrails" (H.H. Esser 1976:599). Within the messianic context of Christ's salvific mission, ta splanchna expresses compassion as an indication of Gods divine involvement with the human predicament of suffering.

28 Noteworthy is the fact that within these texts ta splanchna is connected to illness and health; dying and mourning; loss and grief; violence and injustice; burnt out and hunger, estrangement and remorse.

29 Inbody (1997:140) captures this problem very aptly when he argues that, in our attempt to rethink the meaning of divine power, two things can happen. Our God-image can become 'too small,' or 'too big.' If God can only empathize with the suffering of the world, but can do nothing about it, God is too small. If God is identified with nature, and can do nothing more than what positivists mean by natural law, God is too small. If God is identified with human capacities, abilities, creativity or human ideals, then God is minimalized. On the other hand, if God is identified with omnipotent power, as the kind of power that, because of definition, can do 'just anything,' God is too big. When a theistic notion of divine omnipotence portrays God's kingdom in terms of an empire, He becomes too militant and strong. God is then merely a Hellenistic pantokrator.

30 Feitsma 1956:42: 'Maar als we de noemer aldus onder woorden brengen: natural divina passa est, dan moeten toch al die vormen op deze noemer gebracht worden.' Cf also Feitsma's observation on p.143: 'Ook in het modern theopaschitisme horen we steeds weer dat geluid van Gods eigen lijden. En dat niet 


\section{CONCLUSION}

Ta splanchna describes the praxis of God's being not in substantial categories, but in terms of passion categories: compassion (oiktirmon). Ta splanchna is about a theological beautification of life. It describes the aesthetics of a suffering God. In this regard Browning's reference (1983:13) to David Tracy's conviction that practical theology has primarily to do with the criteria or norms for the transformation of human brokenness, is addressed. Via the passion of Christ in art, our lament about the non-sense in human suffering becomes articulated in divine categories. Even the Jewish artist Marc Chagall used the crucifixion to express the experience of holocaust (Harries 2004:110-11) within the image of a suffering Messiah.

Divine compassion is expressed by the God-image of God as our Companion, Friend for Life. The ontological realm of the aesthetic praxis of God is described by means of metaphorical speech. In this regard the notion of "bowel categories" describes a practical theology of the intestines. The intention and motivation within praxis-actions is the passio Dei. With reference to Vincent Brümmer, one can say: the passio Dei expresses the meaning of Christian faith; it refers to the meanders of a suffering God and is the concrete praxis hermeneutics of the amicitia Dei (Brümmer 2006:299-302). ?? It is only by loving God that we can achieve ultimate happiness and complete fulfilment in our lives? (Brümmer 2006:299). Humane knowing is the spirituality of Christian aesthetics expressed in the mode of compassion and the suffering of sacrificial agape.

The theological telos (teleology) for fides quaerens spem is ta splanchna, i.e. the compassionate 'humanistic praxis' of the Crucified God. Compassionate and redemptive activities as an expression of sensibility, beautifies life. "Primary beauty is an unrestricted benevolence of a generous heart" (Fairley 2001:45). Beauty is not the beast, but transforms beasts into the meaningful passion of compassion, joy and gratitude.

\section{BIBLIOGRAPHY}

Bosch, D J. 1974. Het evangelie in Afrikaans gewaad. Kampen: Kok.

Sölle, D. 1973. Leiden. Stuttgart: Kreuz.

Brümmer, V. 2006. Brümmer on Meaning and the Christian Faith. Aldershot: Ashgate.

Dostoyevski, F. 1973. The Idiot. Harmondsworth: Penguin Books.

Berkhof, H 1973. Christelijk geloof. Nijkerk: Callenbach.

Berkhof, H. 1979. Christian Faith. Grand Rapids: Eerdmans.

Bonhoeffer D. 1970. Widerstand und Ergebung: Briefe und Aufzeichnungen aus der Haft. München: Kaiser. Botha, Paul Emsley. US Woordfees/Wordfest Artist 2012. Retrospective Exhibition. Stellenbosch: Sasol Art Gallery, pp. 5-9.

Browning Don S. 1991. A Fundamental Practical Theology, Minneapolis (Fortress Press), 1991:9-10.

Callahan, D. 1966. The Secular City Debate. New York/London: The Macmillan Company.

Court, J H. 1990. Pornography. In: R J Hunter (ed.), Dictionary of Pastoral Care and Counseling. Nashville: Abingdon, 929-930.

Couvée, P. 2005. Aspects of Sublime and Istinnost in Contemporary Russian Poetry: the Mystic Sublime in the Poetry of Leonid Aronzon and Olga Sedakovs. In: W Van den Bercken, J Sutton, Aesthetics as a Religious Factor in Eastern and Western Christianity. Leuven: Peeters, 81-100.

Cox, H. 1965. The Secular City. London: SCM Press.

Cox, H. 1969. The Feast of Fools. A Theological Essay on Festivity and Fantasy. New York: Harper \& Row Publishers.

De Gruchy, J W. 2001 Christianity, Art and Transformation. Theological Aesthetics in the Struggle for Justice. Cambridge: Cambridge University Press.

als een consequentie van communicatio idiomatum in de ene hypostase van Hem die God en mens is (wie langs deze weg komt tot het spreken over Gods lijden kan zich daaravoor op de Schrift beroepen), masr als typering van Gods diepste wezen.' 
Dissanyake, E. 1992. Homo Aestheticus: Where Art comes from and Why. New York: Free Press.

Dunn, D.G. 1998. The Theology of Paul the Apostle. Grand Rapids: Eerdmans.

Eco, U. 1980. The Name of the Rose. London: Secker \& Warburg.

Eco, U. 2004. On Beauty. London: Secker \& Warburg.

Esser, H.-H. 1976. ioktirmos. In: C. Brown (ed.), Dictionary of New Testament Theology. Vol. 2. Exeter: Paternoster Press, p.598.

Esser, H.-H. 1976. Splanchna. In: C. Brown (ed.), Dictionary of New Testament Theology. Vol. 2. Exeter: Paternoster Press, pp.599-601.

Fairley, E. 2001. Faith and Beauty. A Theological Aesthetic. Aldershot: Ashgate.

Feitsma, M. 1956. Het theopaschitisme: Een dogma-historische studie over de ontwikkeling van het theopaschitisch denken. Kampen: Kok.

Feuerbach, L. 1904. Das Wesen des Christentums. Leipzig: Verlag Philipp Reclam.

Garcia-Rivera, A. 2008. On a New List of Aesthetics Categories. In: O. V. Bycgov, J. Fodor (eds.), Theological Aesthetics after von Balthasar. Aldershot: Ashgate, pp.169-183.

Gräb, W. 2000 Lebensgeshichten, Lebensentwürfe, Sinndeutung. Eine Praktische Theologie gelebter Religion. Gütersloh: Gütersloher Verlagshaus.

Gräb, W. 2002. Sinn furs Unendliche. Religion in der Mediengesellschaft. Gütersloh: Chr. Kaiser/Gütersloher Verlagshaus

Gräb,W. 2006. Sinnfragen. Transformationen des religiösen in der modernen Kultur. Gütersloh: Chr. Kaiser/ Gütersloher Verlagshaus.

Hall, D. 1993. Professing the Faith. Christian Theology in a North Americal Context. Minneapolis: Fortress Press.

Hammarskjöld, D. 1993. Markings. New York: Ballantine Books.

Harries, R. 2004. The Passion in Art. Aldershot: Ashgate.

Hess-Lüttich, W. B., D. Rellstab. 2010. Zeichen/Semiotik der Künste. In: Karlheinz Barck et al, Äesthetische Grundbegriffe. Band 7. Stuttgart/Weimar: Verlag J. B. Metzler, pp. 247-283.

Hermann, J. $2002^{2}$. Sinnmachine Kino. Sinndeutung und Religion im populären Film. Gütersloh: Chr. Kaiser/ Gütersloher Verlagshaus.

Hess, K. 1978. Leitourgeō. In: Brown C (ed.), Dictionary of New Testament Theology, Vol 3 Exeter: Paternoster, 551-553.

Huffinton, A. S. 1988. Picasso. Creator and Destrouer. New York: Simon and Schuster.

Huyghe, R. 1981. Art Forms and Society. In: R Huyge (ed.) Larousse Encyclopedia of Byzantine and Medieval Art. Art and Mankind. London: Hamlyn.

Inbody, T. 1997. The Transforming God: An Interpretation of Suffering and Evil. Louisville/Kentucky:

Westminister John Knox Press.

Jüngel, E. 1967². Gottes Sein ist im Werden. Tübingen: JCB Mohr (Paul Siebeck).

Kaunda, K. 1967². A Humanist in Africa. Letters to Colin Morris. London: Longman.

Kretzschmar, L. 1996. A Holistic Spirituality. A Prerequisite for the Reconstruction of South. In: Journal of Theology for Southern Africa. July 1996, no.95, 63-75.

Kuitert, H. M. 1970. Anders gezegd. Een verzameling theologische opstellen voor de welwillende lezer. Kampen: Kok.

Kuitert, H. M. 1974. Zonder geloof vaart niemand wel. Een plaatsbepaling van Christendom en kerk. Baarn: Ten Have.

La Vita, M. 2012. Die donker in ons almal. In: Die Burger, 20 April, p.13.

Laubach, F. 1967. Der Brief an die Hebräer. Wuppertal: Brockhaus Verlag.

Loen, A. E. 1946. De vaste grond. Amsterdam: H. J. Paris.

Loen, A.E. 1955. Inleiding tot de Wijsbegeerte. 'S-Gravenhage: Boekencentrum.

Loen, A.E. 1965. Säkularisation. München: Kaiser Verlag.

Mandela, N.2005. In the Words of Nelson Mandela. London: Penguin Books.

Mason, A. 2007. A History of Western Art. From Prehistory to the 21st Century. Florence: McRae Books.

Matzker, R. 2008. Ästhetik der Medialität. Zur Vermittlung von künstlerischen Welten und ästhetischen

Theorien. Reinbek bei Hamburg: Rowohlt Tascenbuch Verlag.

Melton, J G et al. 1989. The Churches speak on Pornography. Detroit: Gale Research Inc.

Moltmann, J. 1966 ${ }^{5}$. Theologie der Hoffnung: Untersuchungen zur Begründung und zu den Konsequenzen 
einer christlichen Eschatologie. München: Kaiser.

Moltmann, J. 1972. Der gekreuzigte Gott. München: Kaiser.

Mtetwa, S. 1996. African in the Context of Modernity. Bulletin for Contextual Theology in Southern Africa and Africa 3/2, 21-25.

Néret, G. 2006. Michelangelo 1475-1564. Hong Kong: Taschen.

O'Hear, A. 2007. The Great Books. From the Iliad and the Odyssey to Goethe's Faust: a Journey through 2,500 Years of the West's Classic Literature. Cambridge: Icon Books.

Paris, Y. 2009. Michelangelo 1475-1564. translated buy Sophie Leighton. Bath: Parragon.

Picasso, P. 1988. Picasso. Über Kunst. Aus Gesprächen zwischen Picasso und seinen Freunden. Ausgewählt von Daniel Keel. Mit sieben Zeichnungen des Meisters. Zürich: Diogenes Verlag AG Zürich.

Rebel, J. 1981. Pastoraat in pneumatologisch perspektief. Een theologisch verantwoording vanuit het denken van A. A van Ruler. Kok: Kampen.

Robinson, J.A.T. 1963. Honest to God. London: SCM Press.

Rookmaker, H, R. 1973. Modern Art and the Death of a Culture. [N.p.: n.n.]

Schoeman, K. 2009. Titaan. Roman oor die lewe van Michelangelo Buonarroti. Kaapstad: Human \& Rousseau.

Schulte-Susse, J. 2010. Perspektive/Perspektivismus. In: Karlheinz Barck et al, Äesthetische Grundbegriffe. Band 7. Stuttgart/Weimar: Verlag J. B. Metzler, pp. 758-778.

Skhakhane, J. 1995. African Spirituality. In: M Makobane et al. (Eds.), The church and African culture. Germiston: Lumko.

Skwaran, K. M. 2012. Integritas, Consonanta e Claritas. Reflections on Selected Sculptures and "Drawings with Colour". In Willem Strydom. Stellenbosch: Rupert Museum, pp.3-15.

Smylie, J. H. 1966. Sons of God in the City. In: The Secular City Debate, D Callahan (Ed.). New York/London: Macmillan/ Collier-Macmillan.

Sölle, D. 1973. Leiden. Stuttgart: Kreuz.

Sommer, R. L. 1988. Picasso. London: Bison Books.

Spivey, N. 2006. Wie Kunst die Welt erschuf. Stuttgart: BBC Books.

Stone, K. 2003. Image and Spirit. Finding Meaning in Visual Art. Minneapolis: Augsburg Books.

Wiersinga, H. 1972. Verzoening als verandering. Baarn: Bosch \& Keuning.

Prof D J Louw

Faculty of Theology

Dorpstraat 171

Stellenbosch 7600

Soutj Africa

Email: djl@sun.ac.za 